\title{
Event-related evoked potentials in chronic respiratory encephalopathy
}

This article was published in the following Dove Press journal:

International Journal of COPD

5 February 2010

Number of times this article has been viewed

\author{
A R Al Tahan' \\ R Zaidan' \\ $S$ Jones ${ }^{2}$ \\ A Husain ${ }^{3}$ \\ A Mobeireek' \\ A Bahammam' \\ 'Department of Medicine, \\ ${ }^{3}$ Department of Physiology, College \\ of Medicine, King Saud University, \\ Riyadh, Saudi Arabia; ${ }^{2}$ Department \\ of Neurophysiology, Institute of \\ Neurology, London, UK
}

Background: Cognitive event-related potential $\left(\mathrm{P}_{300}\right)$ is an index of cognitive processing time. It was found to be prolonged in dementia, renal, and hepatic encephalopathies, but was not extensively assessed in respiratory failure.

Objective: To evaluate $\mathrm{P}_{300}$ changes in patients with respiratory failure, and especially those with mild or subclinical hypoxic-hypercapnic encephalopathy.

Methods: Auditory event-related evoked potential $\mathrm{P}_{300}$ latency was measured using an oddball paradigm in patients with respiratory failure due to any cause (partial pressure of oxygen in arterial blood $\left(\mathrm{PO}_{2}\right.$ ) should be $75 \mathrm{~mm} / \mathrm{Hg}$ or less). Apart from blood gases measurement, patients underwent the Mini-Mental State Examination (MMSE). Patient performances were compared with that of matched normal control. Patients were admitted into the study from outpatient clinics and wards at King Khalid University Hospital and Sahara Hospital.

Results: Thirty-four patients (12 women, 22 men) were admitted to the study. Ages ranged from 19-67 years with a mean of 46.1 years. Respiratory failure was severe or very severe in 11 patients $(33 \%)$, and mild or moderate in the rest $(66 \%)$. Mean value for $\mathrm{PO}_{2}$ and partial pressure of carbon dioxide in arterial blood $\left(\mathrm{PCO}_{2}\right)$ were 63.7 and $45.2 \mathrm{~mm} / \mathrm{Hg}$, respectively. $\mathrm{pH}$ mean was 7.4 and $\mathrm{O}_{2}$ saturation was $90.7 \% . \mathrm{P}_{300}$ latency ranged from 218 to 393 milliseconds, with a mean of 338.4 milliseconds. In comparison with control (309.9 milliseconds), there was a significant difference $(P=0.007) . \mathrm{P}_{300}$ amplitude differences were not significant. No significant difference in MMSE was noted between mild and severe respiratory failure. Results of detailed neuropsychological assessment were clearly abnormal but were limited by the small number of tested patients. $\mathrm{P}_{300}$ latency changes correlated significantly with age as well as severity of respiratory failure. $\mathrm{P}_{300}$ was also significantly delayed whether hypoxia occurred with or without hypercapnia.

Conclusion: Results show a significant delay of $\mathrm{P}_{300}$ latency in patients with severe and mild respiratory failure. This was associated with subclinical encephalopathy in most patients, evidenced by a near-normal MMSE score. Apart from confirming the importance of $\mathrm{P}_{300}$ latency measurement as a marker of respiratory encephalopathy, this study asserts the causal relationship between hypoxemia and cognitive derangement. Furthermore, it promotes the early use of oxygen therapy in a selected group of patients with mild or moderate respiratory failure, who have responsibilities which involve taking rapid critical decisions.

Keywords: event-related evoked potentials, hypoxic-hypercapnic encephalopathy, respiratory failure, chronic respiratory encephalopathy

\section{Introduction}

Chronic hypoxic-hypercapnic states occur in many pulmonary and cardiac diseases. These states affect the central nervous system causing well-described nonspecific clinical 
manifestations including headache, dullness of mentation and drowsiness, confusion progressing in severe cases to coma with papilledema, asterixis, action tremor, and muscular twitching. ${ }^{1}$ When these features appear in the context of a severe respiratory failure, the association is clear, and electroencephalography (EEG) shows marked slowing of brain activity. ${ }^{2,3}$ On the other hand, mild chronic hypoxic conditions cause subtle or subclinical changes including inattention, reduction in psychomotor activity, forgetfulness, slight decrease of intelligence, slowing of reaction time, and abnormalities in constructional drawings. ${ }^{4-6}$ Grant and colleagues administered the Halstead-Reitan neuropsychological test battery to patients with chronic obstructive pulmonary disease (COPD), and found their scores to be significantly lower than controls in all tests. ${ }^{5}$ COPD patient performance, particularly in tasks requiring sustained attention, was poor. In these instances, abnormalities of partial pressure of oxygen in arterial blood $\left(\mathrm{PO}_{2}\right)$ and partial pressure of carbon dioxide in arterial blood $\left(\mathrm{PCO}_{2}\right)$ can be easily confirmed by a simple blood test. On the contrary, there is no similar readily available objective tests for the assessment of associated cognitive derangement as structured neuropsychological tests are too complex and timely to be included in the clinical assessment of most patients. Heaton and Pendleton have strongly argued that many of these subtle cognitive impairment affects the quality of various daily activities. ${ }^{7}$ It is expected that such subtle cognitive dysfunction may have serious consequences in situations where patients are involved in activities requiring rapid critical decisions such as operators of complex machines.

Visual-, auditory-, and somatosensory-evoked potentials are well established neurophysiological tests and are widely used in investigating various neurological disorders. ${ }^{8-11}$ Although its value in assessing acute hypoxic states is well established, ${ }^{12,13}$ its benefit in assessing the effect of chronic hypoxic-hypercapnic states on the nervous system was doubtful. ${ }^{14-19}$ Cognitive event-related evoked potentials (EREPs) are long-latency potentials obtained during information processing tasks which involve attention, stimulus discrimination, memory, and related processes. ${ }^{20}$ Among the many EREP components, the $\mathrm{P}_{300}$ potential is the most widely studied and used. It is a positive-going potential with a modal latency of $300 \mathrm{~ms}$ and centroparietal scalp distribution, obtained usually by the oddball paradigm. ${ }^{21} \mathrm{P}_{300}$ latency is an index of cognitive processing time and was shown to be prolonged in normal aging, confusional states, and dementia. ${ }^{22-24}$ $\mathrm{P}_{300}$ latency has been found also to be a sensitive marker of subclinical encephalopathy in hepatic and renal failure. ${ }^{25-28}$ The effect of acute hypoxia on EREP was studied in an experiment that utilized a simulated high altitude environment, and $\mathrm{P}_{300}$ latency was found to be delayed. ${ }^{29}$ So far, few studies have described $\mathrm{P}_{300}$ latency abnormalities in chronic respiratory insufficiency. ${ }^{16,17,30}$ A group of 19 patients with mild or moderate respiratory failure (RF) of different etiologies were studied by Barbieri and colleagues ${ }^{16}$ and another group of 17 patients with variable severity chronic RF by Nakano and colleagues. ${ }^{17}$ Although their results show a tendency for $\mathrm{P}_{300}$ changes, these were not significant. Umahara and colleagues, on the other hand, in a selected group of 14 patients with post pulmonary tuberculosis RF, were able to detect a significant delay in $\mathrm{P}_{300}{ }^{30}$ Taking into account the large variability of $\mathrm{P}_{300}$ latency, these studies are limited by the relatively small number of studied subjects, besides the insignificant results in the first two. This study is designed to examine cognitive EREP in RF in a large group of patients and compare it with mental assessment results and measurement of blood gases. In particular, we aim to determine the sensitivity of $\mathrm{P}_{300}$ changes in detecting mild or subclinical cognitive impairment (ie, subclinical respiratory encephalopathy).

\section{Patients and methods}

Thirty-four patients, 12 females (35.3\%) and 22 males (64.7\%) were admitted to the study from both King Khalid University Hospital and Sahara Hospital out- and inpatient services. All had chronic RF with $\mathrm{PCO}_{2}$ of $75 \mathrm{~mm} / \mathrm{Hg}$ or less, which could be either type I in the presence of hypoxia alone, or type II when combined with hypercapnia. All patients should be able to conduct all required assessments and investigations. Patients with any cause of mental dysfunction apart from RF were excluded. The severity of RF was defined according to $\mathrm{PO}_{2}$ as mild $(75-65 \mathrm{~mm} / \mathrm{Hg})$, moderate $(64-60 \mathrm{~mm} / \mathrm{Hg})$, severe $(59-50 \mathrm{~mm} / \mathrm{Hg})$, and very severe $(<50 \mathrm{~mm} / \mathrm{Hg})$. Patients underwent the following assessments and investigations:

Clinical:

(a) Full neurological assessment

(b) Mini-Mental State Examination (MMSE)

Arterial blood gases:

$$
\mathrm{PO}_{2}, \mathrm{PCO}_{2}, \mathrm{PH} \text {, and } \mathrm{O}_{2} \text { saturation. }
$$

Neurophysiological:

$\mathrm{P}_{300}$ in two-tone oddball paradigm (Figure 1).

Event-related potential recordings were performed using standard methods recommended by the International Federation of Clinical Neurophysiology (IFCN). ${ }^{31}$

\section{Data analysis}

The StatPac Gold (StatPac Inc., Bloomington, MN) statistical analysis package was utilized to analyze the results. 


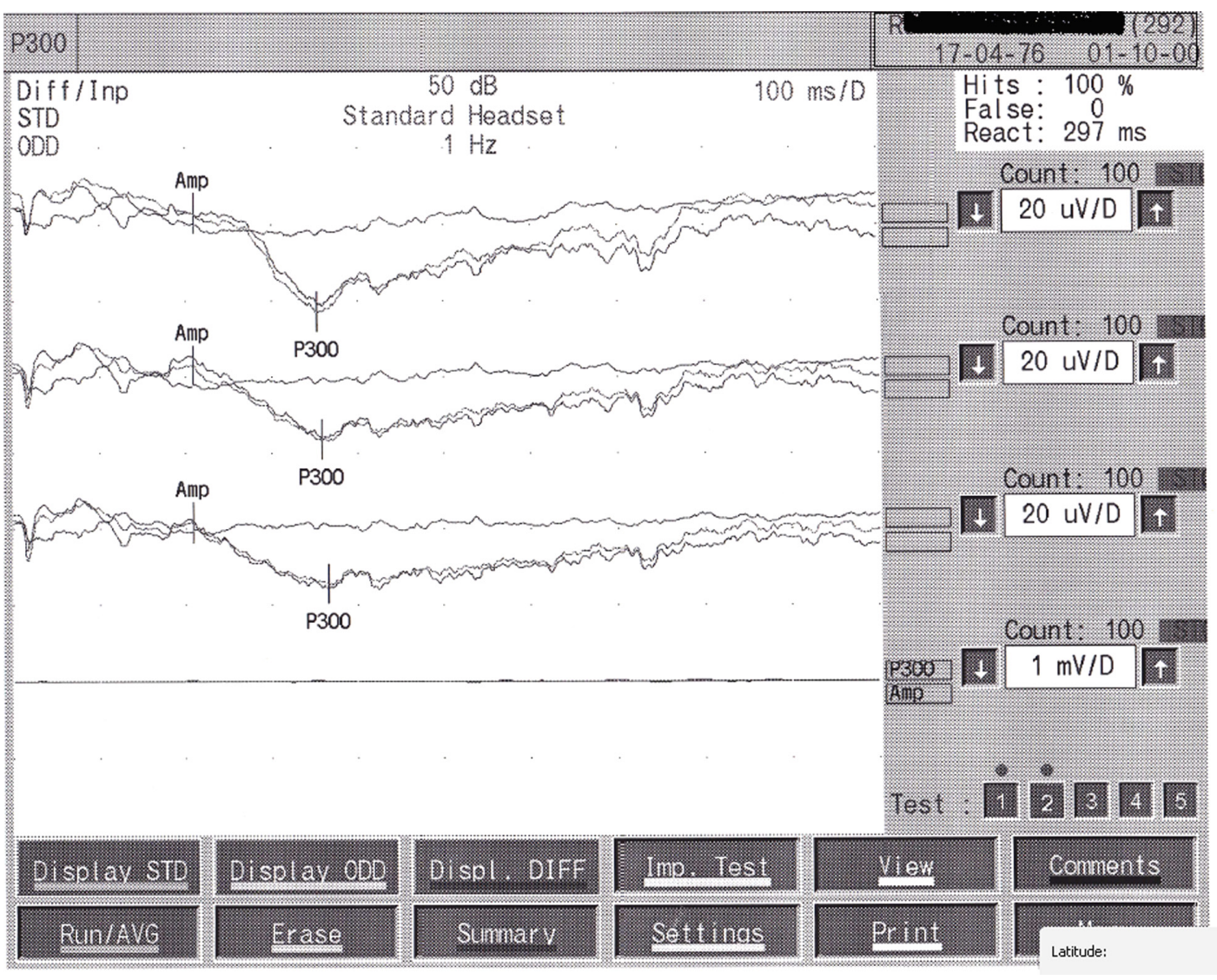

Longitude:

Figure I $\mathrm{P}_{300}$ in two-tone oddball paradigm.

\section{Results}

Patient ages ranged from 19 to 67 years with a mean of $46.4 \pm$ 11.6 years. Eight were below the age of 40 years $(25.8 \%)$, $22(61.3 \%)$ were aged $40-59$ years, and four $(12.9 \%)$ were older than 60 years. Biodata, $\mathrm{P}_{300}$ latency and amplitude, blood gases results, and MMSE scores are included in Table 1.

Thirty-six controls matched for age, sex, and education level were included. Their demographic data and results of $\mathrm{P}_{300}$ latency and amplitude measurements are included in Table 2.

Fourteen patients $(40 \%)$ had severe or very severe RF, and $60 \%$ had mild to moderate severity RF.

The mean value for $\mathrm{PO}_{2}$ and $\mathrm{PCO}_{2}$ were $63.7 \pm 14.3 \mathrm{~mm} / \mathrm{Hg}$ (range from $32-90.7 \mathrm{~mm} / \mathrm{Hg}$ ), and $45.26 \pm 10.68 \mathrm{~mm} / \mathrm{Hg}$ (range from $30-79.8 \mathrm{~mm} / \mathrm{Hg}$ ) respectively. Mean value for $\mathrm{pH}$ was $7.4 \pm 0.34$ and $90.7 \% \pm 7.2 \%$ for $\mathrm{O}_{2}$ saturation. MMSE scores ranged from 22-30 with a mean of $26.1 \pm 2.02$. Table 3 summarizes these results. No significant difference in MMSE could be found between different subtypes of RF.

$\mathrm{P}_{300}\left(\mathrm{C}_{\mathrm{z}}\right)$ latencies in patients ranged from 268 to $393 \mathrm{~ms}$, with a mean of $339.29 \pm 54.26 \mathrm{~ms} . \mathrm{P}_{300}$ amplitude was extremely variable at $13.52 \pm 11.3 \mu \mathrm{v}$. The mean $\mathrm{P}_{300}$ latency in controls was $309.96 \pm 29.15 \mathrm{~ms}$, ranging from $220-372 \mathrm{~ms}$, and $\mathrm{P}_{300}$ amplitude mean was $15.08 \pm 6.43 \mu \mathrm{v}$. EREP results for patients and controls are summarized in Table 4.

$\mathrm{P}_{300}$ latency $\left(\mathrm{C}_{\mathrm{z}}\right)$ was higher among patients than controls (339.29 $\pm 54.26 \mathrm{~ms}$, vs $309.97 \pm 27.08 \mathrm{~ms})$, and was also higher for $\mathrm{P}_{\mathrm{z}}$ measurements $(339.06 \pm 54.88 \mathrm{~ms}$, vs $310.49 \pm$ $31.11 \mathrm{~ms})$. The differences were statistically significant for both measurements ( $P=0.005$ and 0.008 , respectively).

The mean $\mathrm{P}_{300}$ latency from all measurements was also significantly higher in patients than controls (338.44 \pm $53.99 \mathrm{~ms}$ vs $309.96 \pm 29.15 \mathrm{~ms} ; P=0.007)$.

$\mathrm{P}_{300}$ amplitude at $\mathrm{C}_{\mathrm{z}}$ and $\mathrm{P}_{\mathrm{z}}$ were lower in patients than controls $(16.68 \pm 7.39 \mu \mathrm{v}$ vs $13.52 \pm 11.3 \mu \mathrm{v}$ and $13.48 \pm 6.05 \mu \mathrm{v}$ vs $11.41 \pm 9.14 \mu \mathrm{v}$, respectively), but were not statistically significant. Also the mean $\mathrm{P}_{300}$ amplitude difference was not statistically significant $(13.42 \pm 12.2 \mu \mathrm{v}$ vs $15.08 \pm 6.43 \mu \mathrm{v}$, respectively) between both groups. The mean $\mathrm{P}_{300}$ latency in patients changed from $324.2 \mathrm{~ms}$ in mild $\mathrm{RF}$ to $367.3 \mathrm{~ms}$ in very severe RF.

There is a moderate correlation between age and the mean $\mathrm{P}_{300}$ (latency) in cases $(\mathrm{r}=0.54, P=0.001)$, but not in controls 
Table I Biodata and results of blood gases, EREP, and MMSE in 34 patients

\begin{tabular}{|c|c|c|c|c|c|c|c|c|c|c|c|c|c|c|}
\hline \multirow{2}{*}{$\begin{array}{l}\text { Serial no } \\
\mathrm{I}\end{array}$} & \multirow{2}{*}{\begin{tabular}{|l|} 
File no \\
466650 \\
\end{tabular}} & \multirow{2}{*}{$\begin{array}{l}\text { Sex } \\
F\end{array}$} & \multirow{2}{*}{$\begin{array}{l}\text { Age } \\
43\end{array}$} & \multirow{2}{*}{$\begin{array}{l}\mathrm{PO}_{2} \\
47.2\end{array}$} & \multirow{2}{*}{$\begin{array}{l}\mathrm{PCO}_{2} \\
71.4\end{array}$} & \multirow{2}{*}{$\begin{array}{l}\mathbf{P H} \\
7.360\end{array}$} & \multirow{2}{*}{$\begin{array}{l}\mathbf{O}_{2} \\
\text { Sat \% } \\
80.9\end{array}$} & \multicolumn{3}{|c|}{$\begin{array}{l}F_{z} C_{z} P_{z} \\
\text { Latency ms }\end{array}$} & \multicolumn{3}{|c|}{$\begin{array}{l}\mathbf{F}_{\mathrm{z}} \mathbf{C}_{\mathrm{z}} \mathbf{P}_{\mathrm{z}} \\
\text { Amplitude } \mu \mathbf{v}\end{array}$} & \multirow{2}{*}{$\begin{array}{l}\text { MMSE } \\
24\end{array}$} \\
\hline & & & & & & & & 327 & 328 & 329 & 1.17 & 0.10 & 0.85 & \\
\hline 2 & 508904 & $M$ & 53 & 39.7 & 35.3 & 7.464 & 78.2 & 326 & 332 & 344 & 10.40 & 8.05 & 7.11 & 25 \\
\hline 3 & 596577 & $\mathrm{~F}$ & 31 & 51.2 & 49.2 & 7.401 & 86.0 & 304 & 302 & 306 & 5.57 & 8.99 & 9.27 & 24 \\
\hline 4 & $34657 \mid$ & $M$ & 62 & 75.2 & 44.5 & 7.400 & 95.0 & 359 & 358 & 358 & 9.27 & 8.93 & 11.00 & 23 \\
\hline 5 & 596731 & $M$ & 39 & 56.9 & 40.6 & 7.442 & 91.8 & 322 & 326 & 329 & 11.40 & 19.40 & 18.20 & 24 \\
\hline 6 & 055464 & $M$ & 45 & 32.0 & 64.2 & 7.353 & 63.2 & 332 & 332 & 332 & 4.97 & 4.36 & 6.69 & 26 \\
\hline 7 & 543238 & $M$ & 54 & 64.6 & 46.5 & 7.378 & 93.2 & 362 & 368 & 368 & 15.50 & 11.40 & 9.48 & 25 \\
\hline 8 & 460117 & $M$ & 53 & 47.2 & 49.7 & 7.362 & 84.2 & 392 & 393 & 397 & 52.80 & 20.80 & 11.60 & 24 \\
\hline 9 & 416512 & $M$ & 65 & 52.2 & 43.7 & 7.424 & 88.2 & 383 & 382 & 382 & 9.88 & 6.06 & 7.77 & 27 \\
\hline 10 & | 47927 & M & 67 & 49.6 & 52.2 & 7.379 & 83.6 & 549 & 558 & 554 & 20.30 & 12.10 & 7.36 & 28 \\
\hline 11 & $4 \mid 4386$ & $M$ & 55 & 69.9 & 34.6 & 7.443 & 93.7 & 299 & 302 & & 10.60 & 15.90 & & 30 \\
\hline 12 & 159095 & $M$ & 30 & 52.1 & 49.3 & 7.378 & 84.1 & 304 & 283 & 282 & 16.20 & 13.50 & 7.7I & 27 \\
\hline 13 & 206853 & $M$ & 36 & 40.8 & 49.2 & 7.373 & 81.5 & 251 & 268 & 268 & 3.98 & 9.64 & 14.50 & 24 \\
\hline 14 & 606009 & $M$ & 46 & 62.5 & 40.6 & 7.450 & 92.5 & 294 & 295 & 306 & 7.89 & 15.60 & 12.80 & 27 \\
\hline 15 & 611416 & $M$ & 36 & 74.5 & 41.2 & 7.397 & 97.6 & & 202 & 208 & 11.30 & 9.80 & 3.35 & 25 \\
\hline 16 & 096204 & $M$ & 57 & 65.5 & 43.1 & 7.398 & 93.0 & 352 & 352 & 352 & 23.60 & 18.30 & 14.90 & 29 \\
\hline 17 & 111112 & $\mathrm{~F}$ & 37 & 57.7 & 48.3 & 7.349 & 88.4 & 340 & 329 & 320 & 8.62 & 7.86 & 5.79 & 26 \\
\hline 18 & 618472 & $\mathrm{~F}$ & 50 & 54.0 & 65.5 & 7.398 & 86.8 & 368 & 372 & 367 & 9.23 & 16.70 & 10.80 & 25 \\
\hline 19 & 612457 & $M$ & 46 & 68.5 & 38.9 & 7.413 & 93.0 & 329 & 332 & 338 & 15.80 & 16.40 & 15.40 & 27 \\
\hline 20 & 005619 & $\mathrm{~F}$ & 40 & 67.4 & 39.8 & 7.431 & 96.6 & 311 & 308 & 312 & 15.60 & 20.40 & 17.00 & 28 \\
\hline 21 & 345696 & $\mathrm{~F}$ & 50 & 75.7 & 37.9 & 7.409 & 96.0 & 387 & 391 & 398 & 10.40 & 8.05 & 7.16 & 26 \\
\hline 22 & 229859 & $M$ & 38 & 57.9 & 39.5 & 7.423 & 92.6 & 378 & 374 & 374 & 4.99 & 9.01 & 10.40 & 25 \\
\hline 23 & 055464 & $M$ & 45 & 75.7 & 79.8 & 7.338 & 95.0 & 378 & 362 & 245 & 14.00 & 10.40 & 13.20 & 28 \\
\hline 24 & 252915 & $M$ & 38 & 58.5 & 47.1 & 7.407 & 90.3 & 351 & 332 & 331 & 6.59 & 3.10 & 2.54 & 24 \\
\hline 25 & 344947 & $\mathrm{~F}$ & 65 & 75.9 & 37.4 & 7.449 & 95.0 & 355 & 358 & 358 & 3.29 & 3.10 & 1.18 & 25 \\
\hline 26 & 393969 & $\mathrm{~F}$ & 50 & 75.2 & 44.0 & 7.394 & 96.8 & 336 & 336 & 338 & 18.10 & 16.70 & 17.40 & 26 \\
\hline 27 & $53567 \mid$ & $\mathrm{F}$ & 52 & 75.2 & 44.1 & 7.400 & 96.1 & 345 & 341 & 338 & 16.00 & 11.20 & 7.99 & 30 \\
\hline 28 & 591569 & $M$ & 19 & 73.7 & 38.2 & 7.374 & 94.5 & 309 & 308 & 305 & 8.05 & 16.40 & 20.60 & 27 \\
\hline 29 & 596133 & $M$ & 46 & 66.1 & 35.1 & 7.443 & 94.0 & 327 & 336 & 348 & 21.10 & 18.30 & 16.80 & 28 \\
\hline 30 & 472146 & $M$ & 58 & 72.8 & 30.9 & 7.463 & 95.5 & 330 & 334 & 334 & 101.60 & 68.50 & 53.60 & 29 \\
\hline 31 & 568092 & $\mathrm{~F}$ & 40 & 65.6 & 44.2 & 7.351 & 91.9 & 318 & 318 & 319 & 22.20 & 25.30 & 14.60 & 24 \\
\hline 32 & 016557 & $\mathrm{~F}$ & 58 & 70.3 & 40.7 & 7.396 & 94.1 & 311 & 312 & 312 & 0.73 & 6.76 & 10.10 & 22 \\
\hline 33 & 514339 & $\mathrm{~F}$ & 40 & 75.9 & 33.6 & 7.394 & 96.6 & 390 & 395 & 395 & 21.90 & 10.70 & 5.65 & 28 \\
\hline 34 & 550413 & $M$ & 26 & 64.8 & 38.7 & 7.421 & 93.0 & 319 & 309 & 309 & 6.49 & 7.86 & 3.59 & 27 \\
\hline
\end{tabular}

Abbreviations: EREP, event-related evoked potentials; MMSE, Mini-Mental State Examination; $\mathrm{PO}_{2}$, partial pressure of oxygen in arterial blood; $\mathrm{PCO}_{2}$, partial pressure of carbon dioxide in arterial blood.

( $\mathrm{r}=0.06, P=0.71)$. The correlation between age and mean $\mathrm{P}_{300}$ amplitude was weak for cases and controls $(\mathrm{r}=0.17$, $P=0.32$ and $\mathrm{r}=0.07, P=0.67$, respectively).

\section{Discussion}

This study clearly confirm the occurrence of $\mathrm{P}_{300}$ latency delay in association with RF. This is consistent with results obtained by Umahara and colleagues in their selected group of 14 patients with postpulmonary tuberculosis $\mathrm{RF} .{ }^{30} \mathrm{P}_{300}$ latency is already experimentally proven as marker of cognitive function (central processing time), and its delay has already been documented in other metabolic encephalopathies. Of special importance is the fact that significant $\mathrm{P}_{300}$ latency changes were observed in association with various degrees of $\mathrm{RF}$, including the mild or subclinical states. Most patients with mild RF in this study had no or some nonspecific complaints, such as headache, concentration, and memory difficulties, which usually do not raise significant clinical concern. Furthermore MMSE was 
Table 2 Biodata and results of P300 in 36 normal controls

\begin{tabular}{|c|c|c|c|c|c|c|}
\hline Serial no & Hospital no & Age & Sex & Education/Work & $\mathbf{P}_{300}$ Latency ms & $\mathbf{P}_{300}$ Amplitude $\mu \mathrm{v}$ \\
\hline $\mathrm{I}$ & 111111 & 44 & $M$ & College level & 372 & 18.1 \\
\hline 2 & 580776 & $4 I$ & $\mathrm{~F}$ & College level & 313 & 13.2 \\
\hline 3 & 068562 & 68 & $\mathrm{~F}$ & College level & 328 & 14.9 \\
\hline 4 & 170476 & 57 & $\mathrm{~F}$ & College level & 356 & 19.3 \\
\hline 5 & 155210 & 38 & $\mathrm{~F}$ & College level & 308 & 16.3 \\
\hline 6 & 224721 & 57 & $\mathrm{~F}$ & College level & 309 & 28.2 \\
\hline 7 & 382234 & 42 & M & College level & 288 & 26.3 \\
\hline 8 & 103774 & 49 & $\mathrm{~F}$ & College level & 334 & 20.0 \\
\hline 9 & 050455 & 58 & $\mathrm{~F}$ & College level & 290 & 23.3 \\
\hline 10 & 312645 & 55 & M & College level & 220 & 14.5 \\
\hline II & 149844 & 53 & $\mathrm{~F}$ & College level & 283 & 24.9 \\
\hline 12 & 339360 & 45 & $\mathrm{~F}$ & College level & 361 & 11.0 \\
\hline 13 & 123784 & 51 & $\mathrm{~F}$ & College level & 295 & 19.6 \\
\hline 14 & $21904 \mid$ & 56 & $\mathrm{~F}$ & College level & 344 & 5.83 \\
\hline 15 & 469789 & 43 & M & Secondary level & 316 & 10.7 \\
\hline 16 & 338830 & 50 & $\mathrm{~F}$ & College level & 258 & 10.3 \\
\hline 17 & 344239 & 53 & $\mathrm{~F}$ & College level & 301 & 26.9 \\
\hline 18 & 123456 & 54 & $\mathrm{~F}$ & Secondary level & 305 & 21.1 \\
\hline 19 & 041768 & 45 & $\mathrm{~F}$ & Secondary level & 312 & 9.05 \\
\hline 20 & 001020 & 63 & M & Secondary level & 333 & 16.2 \\
\hline 21 & 015408 & 55 & M & Secondary level & 290 & 23.9 \\
\hline 22 & 035526 & 62 & M & Secondary level & 306 & 10.1 \\
\hline 23 & 002477 & 58 & M & Secondary level & 302 & 22.4 \\
\hline 24 & 028034 & 48 & M & Secondary level & 274 & 5.98 \\
\hline 25 & 070112 & 48 & M & Secondary level & 308 & 33.8 \\
\hline 26 & 018549 & 57 & M & College level & 309 & 7.06 \\
\hline 27 & 396058 & 46 & M & College level & 328 & 15.3 \\
\hline 28 & 712658 & 62 & M & College level & 355 & 22.8 \\
\hline 29 & 851708 & 56 & M & College level & 308 & 38.3 \\
\hline 30 & 417765 & 55 & M & Secondary level & 301 & 13.1 \\
\hline 31 & 123456 & 52 & M & Secodary level & 333 & 21.1 \\
\hline 32 & 026199 & 50 & M & Secondary level & 338 & 8.9 \\
\hline 33 & 123456 & 44 & M & College level & 274 & 20.7 \\
\hline 34 & 000440 & 47 & M & College level & 319 & 15.1 \\
\hline 35 & 000112 & 47 & M & College level & 323 & 15.4 \\
\hline 36 & 000000 & 40 & $\mathrm{~F}$ & Secondary level & 308 & 13.1 \\
\hline
\end{tabular}

Table 3a Summary of results blood gases and MMSE in 34 patients with respiratory failure

\begin{tabular}{llllll}
\hline Blood gas $\mathbf{N}=34$ & Minimum & Maximum & Mean & Median & Standard deviation \\
\hline $\mathrm{PO}_{2}$ & 32.0 & 90.7 & 63.72 & 65.15 & 14.34 \\
$\mathrm{PCO}_{2}$ & 30.0 & 79.8 & 45.26 & 43.4 & 10.78 \\
$\mathrm{PH}$ & 7.34 & 7.46 & 7.4 & 7.4 & 0.34 \\
$\mathrm{O}_{2}$ saturation & 63.2 & 99.6 & 90.71 & 93.0 & 7.36 \\
MMSE & 22.0 & 30.0 & 26.09 & 26.0 & 2.02 \\
\hline
\end{tabular}

Abbreviations: MMSE, Mini-Mental State Examination; $\mathrm{PO}_{2}$, partial pressure of oxygen in arterial blood; $\mathrm{PCO}_{2}$, partial pressure of carbon dioxide in arterial blood. 
Table 3b Data of neuropsychological findings in five patients who underwent a full battery of neuropsychological assessments

\begin{tabular}{llll}
\hline Test & Mean & $\begin{array}{l}\text { Standard } \\
\text { deviation }\end{array}$ & Assessment \\
\hline Digit span (forward) & 3.2 & 1.78 & Very poor \\
$\begin{array}{l}\text { Verbal immediate } \\
\text { recall }\end{array}$ & 8 & 2.9 & $\begin{array}{l}\text { Acceptable, } \\
\text { but slightly low }\end{array}$ \\
Verbal delayed recall & 6.4 & 2.6 & Poor \\
Verbal fluency & 26.1 & 1.64 & Good \\
Raven's test & 19.0 & 6.44 & Poor \\
\hline
\end{tabular}

found to be insensitive in most of these patients. $\mathrm{P}_{300}$ latency may be of special importance in this group of patients that demonstrate the presence of definite, though subtle, cognitive derangement. This is because patients at this stage may be executing or undertaking complicated or risky tasks unaware that their mental performance is compromised. Misjudgments or miscalculated decisions may have serious consequences, increase the burden of stress, precipitate work and home difficulties, and possibly emotional disturbances, including depression. Different studies has been able to document subtle cognitive derangements in subclinical respiratory encephalopathy using detailed neuropsychological assessments. ${ }^{4-6}$ In such patients, $\mathrm{P}_{300}$ measurement will be an objective method in assessing cognitive derangement and confirming the presence of 'subclinical' respiratory encephalopathy.

On another front, $\mathrm{P}_{300}$ derangement occurs in both types of RF, and Its latency correlated well with severity of hypoxemia in both types. In type $2 \mathrm{RF}$, it may be partially responsible, however, in type 1 it is the only culprit. The question which arises here is whether correction of hypoxemia, however mild, may be of help in correcting the associated cognitive derangements. In cases of overt clinical respiratory

Table 4 Summary of results of EREPs in 34 patients with chronic respiratory failure and their controls

\begin{tabular}{llll}
\hline EREP & Cases $(\mathbf{X} \pm \mathbf{S D})$ & Controls $(\mathbf{X} \pm \mathbf{S D})$ & $\mathbf{t}$ \\
\hline $\mathrm{F}_{\mathrm{z}}$ (latency) & $339.29 \pm 54.26 \mathrm{~ms}$ & $309.97 \pm 27.08$ & $0.005^{*}$ \\
$\mathrm{C}_{\mathrm{z}}$ (latency) & $339.06 \pm 54.88 \mathrm{~ms}$ & $310.49 \pm 3 \mathrm{I} .1 \mathrm{I}$ & $0.008^{*}$ \\
$\mathrm{P}_{\mathrm{z}}$ (latency) & $338.06 \pm 56.72 \mathrm{~ms}$ & $309.43 \pm 31.17$ & $0.0 \mathrm{I}^{*}$ \\
$\mathrm{~F}_{\mathrm{z}}$ (amplitude) & $15.28 \pm 17.9 \mathrm{I} \mu$ & $15.08 \pm 7.64$ & 0.95 \\
$\mathrm{C}_{\mathrm{z}}$ (amplitude) & $13.52 \pm 11.30 \mu \mathrm{v}$ & $16.68 \pm 7.39$ & 0.165 \\
$\mathrm{P}_{\mathrm{z}}$ (amplitude) & $\mathrm{II} .4 \mathrm{I} \pm 9.14 \mu \mathrm{v}$ & $13.48 \pm 6.05$ & 0.263 \\
Mean $\mathrm{P}_{300}$ latency & $338.44 \pm 53.99 \mathrm{~ms}$ & $309.96 \pm 29.15$ & $0.007^{*}$ \\
Mean $\mathrm{P}_{300}$ amplitude & $13.42 \pm 12.9 \mu \mathrm{v}$ & $15.08 \pm 6.43$ & $0.47 \mathrm{I}$ \\
\hline
\end{tabular}

Abbreviations: EREP, event-related evoked potentials; $P_{300}$, cognitive event-related potential;SD, standard deviation. encephalopathy associated with severe hypoxemia, the use of oxygen led to clear mental improvement, which formed the basis for portable oxygen therapy. Should portable oxygen be offered to patients with a milder degree of RF, especially those undertaking sophisticated, specialized professions? Results of the present study clearly goes in favor of such a decision, as the use of $\mathrm{P}_{300}$ latency as the marker of processing time was found to be prolonged in most of these patients. However a more definite answer to this question is expected from a prospective interventional study, where $\mathrm{P}_{300}$ latency is assessed before and after administering oxygen.

Finally, $\mathrm{P}_{300}$ latency varies widely in normal subjects, making measurements of individual patients of little use generally. Although we were able to establish a normal $\mathrm{P}_{300}$ latency value with a two standard-error range in this study, the practical use of these absolute values in individual patients will require prolonged experience. The main benefit of this potential will be in assessing the benefit of a therapeutic modality, ie, oxygen, in a group of patients with respiratory encephalopathy. Or conversely, assessing the effect of any medicine used for other reasons on exacerbating encephalopathy. Taking into account the fact that all patients in the group of mild encephalopathy do not use oxygen therapy, it is reasonable to suggest that at least some of those patients may benefit from an earlier introduction of such treatment, especially a subgroup of patients holding critical responsibilities, in whom cognitive dysfunction may affect their optimum performance.

\section{Acknowledgments}

The authors would like to acknowledge the generous grant of King Abdulaziz City for Science and Technology (KACST) for this project (Limited Grant Project No. 3-25). Without such support this work would not have been completed. The authors are also grateful to the help of other staff including technicians, secretaries, and research assistants at King Khalid University Hospital and Sahara Hospital.

\section{References}

1. Adams R, Victor M. The acquired metabolic disorders of the neuron systems. In: Principles of Neurology. New York, NY: McGraw Hill; 1993;5:877-902.

2. Labram C, Bursauxe M, Baudouin R, Gaillot MJ. L'encephalopathie respiratoire. Hypertension intracanienne ave oedeme papillaire et hemorragies retiniennes au cours d'une insuffisance respiratoire chroniique meconnue. Presse Med. 1966;74:2465-2468.

3. Meyer JS, Gotoh H, Tomita A. Acute respiratory acidemia correlation of jugular blood composition and electroencephalogram during $\mathrm{CO}_{2}$ narcosis. Neurology. 1969;16:463-474.

4. Flenley DC. Clinical hypoxia: causes, consequences and correction. Lancet. 1978;1:542-546. 
5. Grant I, Heaton RK, McSweeny AJ, Adams KM, Timms RM. Neuropsychologic findings in hypoxemic chronic obstructive pulmonary disease. Arch Intern Med. 1982;142:1470-1476.

6. Prigatano GP, Parsons O, Wright E, Levin DC, Hawryluk G. Neuropsychologic test performance in mildly hypoxemic patients with chronic obstructive pulmonary disease. J Cons Clin Psychol. 1983;51: 108-116.

7. Heaton RK, Pendleton MG. Use of neuropsychological test to predict adult patient's everyday functioning. J Cons Clin Psychol. 1981;49: 807-821.

8. Celesia GG, Brigell MG. Pattern visual stimulation in pre-chiasmatic lesions. Visual Evoked Potentials. 1990:76.

9. Kono, Yeda Y, Nakajima K, Araki K, Kagawa K, Kashima K. Subcortical impairment in subclinical hepatic encephalopathy. J Neurol Sci. 1994;126(2):162-167.

10. Aminoff MJ. Brainstem auditory evoked potentials in neurology: Methodology, interpretation, and clinical application. In: Stockard J, Pope-Stockard JE, Sharbrough FW, editors. Electrodiagnosis in Clinical Neurology. 1992:503-536.

11. Eisen A. The use of somatosensory evoked potentials for the evaluation of the peripheral nervous system. Neurol Clin. 1988;6:825-838.

12. Tsuyama N, Tsuzuki N, Kurokawa T, Imai T. Clinical application of spinal cord action potential measurement. Int Orthop. 1978; 2:39-44.

13. Iwayama K, Mori K, Sakai S, Yamashiro K, Iwamoto K. The changes of somatosensory evoked potentials accompanying ischaemia and hypoxia in cats. Neurol Res. 1986;8:157-163.

14. Mabin D, Borsotti JP, Le Mevel JC, Tea S, Calvier J. Value of visual and somatosensory evoked potentials and the electroencephalogram in chronic respiratory insufficiency. Rev Electroencephalogr Neurophysiology Clin. 1985;15:53-57.

15. Zeitlhofer J, Graf M, Mamoli B, Schilc K, Kummer F, Haber P. Neurophysiologic studies in Pickwickian syndrome. Nervenarzt. 1986;57:262-268.

16. Barbieri S, Fayoumi XZ, Berardinelli P, et al. Evidence of a subclinical involvement of central nervous system in mild or moderate chronic respiratory insufficiency. Electromyogr Clin Neurophysiol. 1996;36:67-72.

17. Nakano S, Inamura S, Tokunaga K, Tsuji S, Hashimoto I. Evoked potentials in patients with chronic respiratory insufficiency. Intern Med. 1997;36:270-275

18. Paquereau J, Maurice JC, Neau JP, Ingrand P, Patte F. Auditory brain stem responses (ABRs) in sleep respiratory disorders. Eur J Clin Invest. $1994 ; 24: 156-160$
19. Barlieri S, Fayoumi Z, Berardinelli P, et al. Evidence for a subclinical involvement of the central nervous system in mild or moderate chronic respiratory insufficiency. Electroenceph Clin Neurophysiol. 1996;36:67-72.

20. Polich J. P300 in clinical applications: meaning, method, and measurement. In: Neidemeyer E, Da Silva FL, editors. Electroencephalography: Basic Principles, Clinical Applications, and Related Fields, 3rd edition. Philadelphia, PA: Lippincott Williams \& Wilkins; 1993. p. 1005-1018.

21. Polich J, Kok A. Cognitive and biological determinants of P300: an integrative review. Biol Psychol. 1995;41:103-146.

22. Goodin DS, Starr A, Chippendale T, Squires KC. Sequential changes in the P3 component of the auditory evoked potential in confusional states and dementing illnesses. Neurology. 1983;33:1215-1218.

23. Slaets JPJ, Fortgene C. On the value of $\mathrm{P}_{300}$ event-related potentials in the different diagnosis of dementia. Br J Psychiatry. 1984;145:652-656.

24. Polich J, Ehlens CL, Otis S. $P_{300}$ latency reflects the degree of cognitive decline in dementing illness. Electroencephalogr Clin Neurophysiol. 1986;63:138-144.

25. Davies MG, Rowan MJ, Feely J. EEG and event-related potentials in hepatic encephalopathy. Metab Brain Dis. 1991;6:175-186.

26. Kyler CF, Lotterer E, Petter J, et al. Visual event-related $\mathrm{P}_{300}$ potentials in early portosystemic encephalopathy. Gastroenterology. 1992;103: 302-310.

27. Davies MG, Rowan MJ, MacMathuna P, Keeling PW, Weir OG, Feely J. The auditory P300 event-related potential: an objective marker of the encephalopathy of chronic liver disease. Hepatology. 1990;12: 688-689.

28. Ruzicka E, Tesar V, Jelinkova E, Mmerta M, Nevsimalova S, Kucerova O. Event-related potentials in evaluation of metabolic encephalopathies. Schweiz Arch Neurol Psychiatr. 1993;144:378-384.

29. Wissensten NJ, Crowley J, Balkin T, et al. Effects of stimulated high altitude exposure on long latency event-related brain potentials and performance. Aviat Space Environ Med. 1993;64:30-36.

30. Umahara T, Kiuchi A, Kobayashi Y, Iwamoto T, Takasaki M. $\mathrm{P}_{300}$ latency in patients with respiratory insufficiency due to sequelae of pulmonary tuberculosis. No To Shinkei. 1992;44:19-23.

31. IFCN Committee. IFCN recommended standards for long-term auditory event-related potentials. Electroencephalogr Clin Neurophysiol. 1994;91:18-20.
International Journal of COPD

\section{Publish your work in this journal}

The International Journal of COPD is an international, peer-reviewed journal of therapeutics and pharmacology focusing on concise rapid reporting of clinical studies and reviews in COPD. Special focus is given to the pathophysiological processes underlying the disease, intervention programs, patient focused education, and self management protocols.

\section{Dovepress}

This journal is indexed on PubMed Central, MedLine and CAS. The manuscript management system is completely online and includes a very quick and fair peer-review system, which is all easy to use. Visit http://www.dovepress.com/testimonials.php to read real quotes from published authors. 